\title{
Effects of Angiotensin-Converting Enzyme Inhibition on Circulating Endothelial Progenitor Cells in Patients with Acute Ischemic Stroke
}

\author{
Monika Gołąb-Janowska ${ }^{D},{ }^{1}$ Edyta Paczkowska ${ }^{D},{ }^{2}$ Bogusław Machaliński ${ }^{D}{ }^{2}$ \\ Dariusz Kotlegga, ${ }^{1}$ Agnieszka Meller, ${ }^{1}$ Krzysztof Safranow, ${ }^{3}$ Michal Maj, ${ }^{1}$ \\ and Przemyslaw Nowacki ${ }^{1}$ \\ ${ }^{1}$ Department of Neurology, Pomeranian Medical University, Szczecin, Poland \\ ${ }^{2}$ Department of General Pathology, Pomeranian Medical University, Szczecin, Poland \\ ${ }^{3}$ Department of Biochemistry and Medical Chemistry, Pomeranian Medical University, Szczecin, Poland \\ Correspondence should be addressed to Monika Gołąb-Janowska; monikagj@op.pl
}

Received 7 December 2017; Revised 3 March 2018; Accepted 29 March 2018; Published 26 April 2018

Academic Editor: Giuseppe Mandraffino

Copyright (C) 2018 Monika Gołąb-Janowska et al. This is an open access article distributed under the Creative Commons Attribution License, which permits unrestricted use, distribution, and reproduction in any medium, provided the original work is properly cited.

\begin{abstract}
Background. Therapeutic neovascularization might represent an important strategy to salvage tissue after ischemia. Circulating bone marrow-derived endothelial progenitor cells (EPCs) were previously shown to augment the neovascularization of ischemic tissue. Angiotensin-converting enzyme inhibitors (ACEIs) might modulate EPC mobilization. We evaluated populations of circulating stem cells and early EPCs in acute ischemic stroke (AIS) patients and the effect of ACEI on circulating EPCs in these patients with respect to aspects of stroke pathogenesis. Methods. We studied 43 AIS patients (group I), comprising 33 treated with ACEI (group Ia) and 10 untreated (group Ib). Risk factor controls (group II) included 22 subjects. EPCs were measured by flow cytometry. Results. In AIS patients, the number of circulating stem cells and early EPCs upon admission was similar to that in control group individuals. There were no significant differences in the numbers of stem cells and early EPCs over subsequent days after AIS. There were also no significant differences in stem cell and early EPC numbers over the first 3 days between group Ia and group Ib. However, on day 7, these numbers were significantly higher in group Ib than in group Ia $(p<0.05)$. In AIS patients chronically treated with ACEI, there was a negative correlation between CD133 ${ }^{+}$ cell number and neurological deficit on the first, third, and seventh days $(p<0.005)$. Conclusions. An increased number of circulating stem cells and early EPCs were not observed in stroke patients chronically treated with ACEI. In patients chronically treated with ACEI, a significant correlation was observed between decreased neurological deficit and higher levels of $\mathrm{CD}_{133^{+}}$cells; this could be due to the positive influence of these cells on the regeneration of the endothelium and improved circulation in the ischemic penumbra.
\end{abstract}

\section{Introduction}

Stroke is the third leading cause of death and the most common cause of permanent disability in adults worldwide. Following acute ischemic stroke (AIS), a complicated cascade of biochemical events takes place that involves inflammation, neuronal necrosis, disruption of the blood-brain barrier, and neurological dysfunction [1-4].
The balance between endothelial injury and repair and the turnover of endothelial cells are the major determinants of vascular integrity maintenance. An imbalance represents a key step in atherosclerosis. The number of circulating endothelial progenitor cells (EPCs) can be the result of the ability of the bone marrow to mobilize them. Some of these cells can be destroyed in the circulation due to the various factors (e.g., hypertension, high 
cholesterol levels, and inflammation); the rest are incorporated into the damaged endothelium. In addition, assessing endothelial damage is important when evaluating EPC levels [5].

Endothelial progenitor cells (EPCs) are released from the bone marrow to the peripheral blood and participate in endothelial cell repair and regeneration $[1,5]$. Such EPCs most likely coexpress specific endothelial and progenitor markers such as CD34, CD133, and vascular endothelial growth factor receptor (VEGF-R) [6]. As shown in animal and human models, EPCs contribute to neovascularization and reendothelialization [7]. Clinical studies have revealed that cardiovascular diseases are associated with a dysfunction in EPCs $[8,9]$ and that the number of circulating EPCs correlates positively with clinical outcome [10-13]. Although EPCs might be a potential marker of vascular function in cardiac disease, few studies have delved into the contribution of EPCs to clinical outcome after AIS. Furthermore, the results are conflicting; some studies have reported lower EPC counts in patients with acute stage ischemia compared to that in controls [14-16], whereas other studies have reported the opposite [17-21].

In vitro and clinical studies have shown that drugs used in the treatment of cardiovascular diseases, such as angiotensin-converting enzyme inhibitors (ACEIs), have beneficial effects on EPC mobilization [22, 23]. Experimental studies have also revealed that ACEIs can attenuate the development of atherosclerosis-related diseases independent of their vasodilating and hypotensive effects, and this attenuation might be associated with the modulation of EPC mobilization [24]. In patients with coronary artery disease (CAD), ACEIs have been shown to improve prognosis, although the underlying mechanisms are not fully understood [25]. ACEIs increase the expression of many signaling molecules including vascular endothelial growth factor (VEGF) [24, 26]. These molecules are released into the circulation from the ischemic myocardium and act on the bone marrow to promote the release of EPCs [27].

Taken together, EPC levels are inversely correlated with various risk factors and positively correlated with astrocytes, EPO, and angiogenic T-cells, whereas the relationship between ACEIs and EPCs remains controversial. Despite the above data suggesting both inhibitory, negative effects and enhancing, positive outcomes, it remains unclear whether EPCs play a positive role in AIS [28].

Accordingly, we evaluated the populations of circulating stem cells $\left(\mathrm{CD} 133^{+}\right)$and early EPCs $\left(\mathrm{CD} 133^{+} / \mathrm{VEGFR}^{+}\right)$ in AIS patients, in addition to the functional, chemotactic effect of ACEIs on circulating EPCs in these patients, taking into account aforementioned aspects of stroke pathogenesis.

\section{Materials and Methods}

2.1. Patient Study Group. We prospectively studied 43 consecutive patients with AIS (group I); 33 were treated with an ACEI (group Ia), and 10 were untreated (group Ib). These individuals were admitted to the Department of Neurology,
Pomeranian Medical University in Szczecin. All patients were enrolled in the study within the first 24 hours after the onset of stroke.

The number of patients studied on day 3 was 37 (27 for group Ia, 10 for group Ib); no sample was available in cases of defective blood sampling $(n=6)$. The number of patients studied on day 7 was 32 ( 25 for group Ia, 7 for group Ib); no sample was available from the remaining patients due to death $(n=2)$, early discharge $(n=4)$, or defective blood sampling $(n=5)$.

Exclusion criteria were as follows: a previously modified Rankin scale [29] score higher than 2; a National Institute of Health Stroke Scale (NIHSS) [30] score of 0; current history of acute inflammatory disease, chronic inflammatory disease, neoplastic disease, and renal failure; and lack of blood sample processing within 2 hours of collection (the predefined time window for obtaining reliable results). Because our laboratory could process the blood samples only during working days, we excluded patients admitted during the weekend as the sample could not be processed within 2 hours. Risk factor controls (group II) included 22 subjects matched by age, gender, and traditional vascular risk factors (see subsequent sections).

The study adhered to the principles of the Declaration of Helsinki, and approval was obtained from the Local Research Ethics Committee (Szczecin, Poland). Moreover, written informed consent was obtained before patient involvement.

2.2. Clinical Data. We recorded the following data from each patient: demographics (age and sex); presence of traditional vascular risk factors including high blood pressure, diabetes mellitus, hypercholesterolemia, CAD, atrial fibrillation, peripheral artery disease, smoking habits, alcohol abuse, previous transient ischemic attack, and previous cerebral infarction; and treatment with any ACEI before the onset of stroke and during admission.

2.2.1. Risk Factors. Regarding hypertension, patients were diagnosed based on their history, medical records, and drugs taken. Newly detected arterial hypertension was diagnosed when repeated tests showed a systolic blood pressur$\mathrm{e} \geq 140 \mathrm{mmHg}$ and/or a diastolic blood pressure $\geq 90 \mathrm{mmHg}$ [31]. The criteria for diagnosing type 2 diabetes were patient history, medical records, and drugs administered. Confirmation of newly diagnosed diabetes in patients was based on $\mathrm{HbA} 1 \mathrm{c} \geq 6.5 \%$ at admission [32]. Hyperlipidemia (serum cholesterol concentration $>190 \mathrm{mg} / \mathrm{dL}$, LDL cholesterol $>115 \mathrm{mg} / \mathrm{dL}$, or serum triglyceride concentration $>150 \mathrm{mg} / \mathrm{dL}$ ) was assessed as defined previously [33]. Coronary artery disease (CAD) was defined as prior myocardial infarction, angina pectoris, percutaneous coronary intervention, or coronary artery bypass surgery. Following CC/AHA/ESC clinical guidelines, atrial fibrillation was defined as the absence of $\mathrm{P}$ waves in the ECG, with the isoelectric line being replaced by irregular high-frequency oscillations (f waves), and the wholly irregular ventricular response; this was based on ECG results during admission or from previous medical reports [34]. Peripheral arterial 
disease included a previous history of intermittent claudication, arterial thrombosis, and percutaneous or surgical intervention in the thoracic, abdominal aorta, or lower extremity vessels. Current smoking habits were also considered. Moreover, alcohol abuse was taken into account if the consumption of ethyl alcohol by men exceeded $40 \mathrm{~g}$ per day ( $>4$ standard doses of spirits) and $20 \mathrm{~g}$ per day ( $>2$ standard doses) for women [35].

Body mass index was also assessed; a classification of overweight was indicated by a BMI of 25.0-29.9, and obesity was determined with a BMI $>30$. Finally, a history of cerebral vascular episodes was considered. For this, we analyzed stroke etiological subtypes according to the SSS-TOAST classification [36] and severity of the neurological deficit on admission (NIHSS score). Improvement of neurological status was defined as a decrease in the NIHSS score percentage between admission and the seventh day after stroke onset. In each case, the stroke had been precisely documented by computer tomography.

2.3. Laboratory Measurements. EDTA-anticoagulated peripheral blood (PB) samples (two $2.7 \mathrm{~mL}$ specimens) were drawn within 24 hours of stroke onset, as well as on days 3 and 7, from stroke patients, and once from control subjects. The absolute numbers of leukocytes and lymphocytes in $\mathrm{PB}$ were determined using an automatic cell counter (Cell-Dyn 3500, Abbott Diagnostics, Santa Clara, CA, USA). Highsensitivity CRP (hsCRP) was assayed using a latexenhanced immunonephelometric assay on a BN II analyzer (Dade Behring, Newark, DE), whereas fibrinogen was measured on this device by immunoassay. The full population of peripheral blood nucleated cells (PBNCs) was obtained after the lysis of red blood cells using $1 \times \mathrm{BD}$ Pharm Lyse Buffer (Pharmingen, BD Biosciences, San Diego, CA, USA).

2.4. Flow Cytometry. The full population of PBNCs was obtained after the lysis of erythrocytes using BD Pharm Lyse Buffer (Pharmingen, BD Biosciences, San Diego, CA, USA). For flow cytometry, 1 million NCs were resuspended in $100 \mu \mathrm{L}$ of phosphate-buffered saline (PBS). Immunofluorescence cell staining was performed using a phycoerythrin(PE-) conjugated anti-CD309 (VEGFR-2/KDR) antibody (Pharmingen, BD Biosciences, San Jose, USA; clone 89106) and an allophycocyanin- (APC-) conjugated anti-CD133 antibody (Miltenyi Biotec, Auburn, CA, USA; clone AC133). Samples stained with appropriate isotype control antibodies, specifically IgG1-PE (Pharmingen, BD Biosciences, San Jose, USA; clone MOPC-21) and IgG1-APC (Miltenyi Biotec, Auburn, CA, USA), were prepared in parallel and served as negative controls. After $20 \mathrm{~min}$ incubation on ice, the cells were washed twice in PBS and resuspended in 1\% paraformaldehyde. Cell fluorescence was measured, and data were analyzed using an LSRII flow cytometer (BD Biosciences, San Jose, CA, USA) with BD FACSDiva software. Typically, $2 \times 10^{5}$ events were acquired to determine the proportions of examined subpopulations within the PBNCs. Using this approach, populations of circulating stem cells $\left(\mathrm{CD} 133^{+}\right)$ and early EPCs $\left(\mathrm{CD} 133^{+} / \mathrm{VEGFR}^{+}\right)$were analyzed.
2.5. Statistical Methods. The primary objective of this trial was to investigate the alternative hypothesis that ACEI treatment is associated with higher populations of circulating stem cells $\left(\mathrm{CD}_{133^{+}}\right)$and early EPCs $\left(\mathrm{CD} 133^{+} / \mathrm{VEGFR}^{+}\right)$in AIS patients (the biological null hypothesis assumed that ACEI treatment does not increase the number of EPCs in AIS individuals).

There were two main types of variables assessed, namely, quantitative and qualitative.

Because the distribution of quantitative variables was not normal and skewed (Shapiro-Wilk test), the data were compared between the groups using the nonparametric MannWhitney $U$ test. The results of qualitative variables were presented as a number (percentage). Data were compared between the groups using the $\chi^{2}$ test. Correlations between quantitative variables were studied by assessing Spearman's rank correlation coefficient (Rs). Multiple linear regression was used to check whether acetylsalicylic acid treatment, plasma hsCRP, and plasma fibrinogen were independent factors associated with the logarithmically transformed number of $\mathrm{CD}_{133^{+}}$cells or EPCs in group I patients.

All statistical tests were two-tailed, and $p<0.05$ was considered to indicate a statistical significance. All statistical analyses were performed with STATISTICA 10 software.

\section{Results}

Table 1 displays the baseline characteristics of groups I and II. There were no significant differences in terms of these variables between the assessed groups with the exception of higher plasma hsCRP in AIS patients. The numbers of $\mathrm{CD}_{133^{+}}$and $\mathrm{CD} 133^{+} / \mathrm{VEGFR} 2^{+}$cells in groups I and II were also similar $(p>0.05$; Table 2$)$.

In AIS patients, circulating stem cells $\left(\mathrm{CD} 133^{+}\right)$were decreased in the first week, but there were no significant differences in their numbers on subsequent days after AIS $\left(\mathrm{CD} 133^{+} \_1=0.0325 \pm 0.07, \mathrm{CD}_{133^{+}}{ }_{-} 3=0.0177 \pm 0.01\right.$, and $\left.\mathrm{CD}_{133^{+}}{ }^{-}=0.0182 \pm 0.02 ; p>0.05\right)$. Early EPCs $\left(\mathrm{CD} 133^{+} /\right.$ VEGF-R2 ${ }^{+}$) were also decreased during the first week, and there were no significant differences in their numbers at subsequent days after AIS $\left(\mathrm{CD} 133^{+} / \mathrm{VEGF}^{\mathrm{R}} 2^{+} \_1=0.0099 \pm\right.$ $0.022, \mathrm{CD}_{133^{+}} / \mathrm{VEGF}-\mathrm{R} 2^{+}{ }^{+} 3=0.0049 \pm 0.004$, and $\mathrm{CD} 133^{+} /$ VEGF-R $2^{+} 7=0.0048 \pm 0.004 ; p>0.05$ ).

Group Ia consisted of 33 patients treated with ACEI. All patients were treated exclusively with perindopril at $5 \mathrm{mg}$ per day prior to stroke and a stable dose during admission.

As shown in Table 3, group Ia had significantly higher blood hsCRP $(p=0.0223)$ and fibrinogen $(p=0.0478)$ levels than group Ib.

In group Ia, the number of circulating stem cells $\left(\mathrm{CD}_{133^{+}}\right)$and the number of early EPCs $\left(\mathrm{CD}_{133^{+}}{ }^{+}\right.$ VEGFR2 $2^{+}$) were highest on the first day and then decreased on days 3 and 7; however, the differences between the numbers of circulating cells at these time points were not significant $(p>0.05)$. There were only small differences between the number of $\mathrm{CD}_{133^{+}}$cells and the number of $\mathrm{CD} 133^{+} /$ VEGFR $^{+}$cells in group Ib during observation $(p>0.05$; Tables 4 and 5). On days 1 and 3 , the numbers of $\mathrm{CD} 133^{+}$ and $\mathrm{CD}_{133^{+}} / \mathrm{VEGFR}^{+}$cells were not significantly different 
TABLE 1: Clinical characteristics of groups I and II.

\begin{tabular}{|c|c|c|c|}
\hline Clinical feature & Group I $(n=43)$ & Group II $(n=22)$ & \\
\hline Qualitative parameters & $n(\%)$ & $n(\%)$ & $p$ value* \\
\hline Male gender & $20(46.5)$ & $10(45.5)$ & 0.9227 \\
\hline \multicolumn{4}{|l|}{ Sever clinical status } \\
\hline $\mathrm{NIH} \leq 7(\%)$ & $17(39.6)$ & - & \\
\hline NIH 8-17 & $13(30.2)$ & - & \\
\hline $\mathrm{NIH}>18$ & $13(30.2)$ & - & \\
\hline \multicolumn{4}{|l|}{ Neurological status improvement } \\
\hline No improvement & $16(37.2)$ & - & \\
\hline Improvement $<50 \%$ & $13(30.2)$ & - & \\
\hline Improvement $>50 \%$ or complete recovery & $14(32.6)$ & - & \\
\hline Death & $3(7.0)$ & - & \\
\hline Hypertension & $43(100)$ & $20(90.9)$ & 0.2100 \\
\hline Dyslipidemia & $17(39.6)$ & $7(31.8)$ & 0.5419 \\
\hline Diabetes mellitus & $15(34.9)$ & $6(27.2)$ & 0.5347 \\
\hline Current smoking & $8(18.6)$ & $4(18.2)$ & 0.9328 \\
\hline Excessive alcohol intake & $8(18.6)$ & $3(13.6)$ & 0.5858 \\
\hline Obesity & $11(25.6)$ & $4(18.2)$ & 0.5029 \\
\hline Overweight & $20(46.5)$ & $7(31.8)$ & 0.2553 \\
\hline Coronary artery disease & $23(53.5)$ & $7(31.8)$ & 0.0973 \\
\hline Atrial fibrillation & $16(37.2)$ & $6(27.2)$ & 0.4231 \\
\hline ACE inhibitors & $33(76.7)$ & $13(59.1)$ & 0.1387 \\
\hline Aspirin & $18(41.9)$ & $8(36.4)$ & 0.1387 \\
\hline Enoxaparin & $2(4.7)$ & $1(4.5)$ & 0.9847 \\
\hline Quantitative parameters & Mean \pm SD & Mean \pm SD & $p$ value $^{* *}$ \\
\hline Age (y) & $75.2 \pm 11.3$ & $72.6 \pm 9.3$ & 0.1553 \\
\hline Plasma hsCRP (mg/L) & $8.2 \pm 18.3$ & $3.0 \pm 7.6$ & 0.0322 \\
\hline Plasma fibrinogen (mg/dL) & $378.3 \pm 91.5$ & $360 \pm 67.6$ & 0.2517 \\
\hline White blood cells (WBC) (G/L) & $9.5 \pm 3.21$ & $6.6 \pm 2.01$ & 0.5723 \\
\hline Plasma total homocysteine $(\mu \mathrm{mol} / \mathrm{L})$ & $14.2 \pm 8.8$ & $12.0 \pm 6.1$ & 0.4969 \\
\hline \multicolumn{4}{|l|}{ Lipid profile (mg/dl) } \\
\hline Total cholesterol & $178.2 \pm 44.2$ & $176.1 \pm 41.1$ & 0.9117 \\
\hline LDL cholesterol & $111.0 \pm 39.4$ & $101 \pm 31.2$ & 0.3494 \\
\hline HDL cholesterol & $45.5 \pm 13.7$ & $39 \pm 11.2$ & 0.1344 \\
\hline Triglycerides & $113.3 \pm 40.2$ & $99 \pm 30.2$ & 0.3050 \\
\hline
\end{tabular}

${ }^{*}$ Chi-squared test. ${ }^{* *}$ Mann-Whitney $U$ test.

TABLE 2: Circulating stem cells $\left(\mathrm{CD} 133^{+}\right)$and early EPCs $\left(\mathrm{CD} 133^{+} /\right.$ VEGFR2 ${ }^{+}$) in groups I (at the first time point-24h) and II.

\begin{tabular}{lccc}
\hline $\begin{array}{l}\text { Study population } \\
\text { (Number of cells } / \mu \mathrm{L})\end{array}$ & $\begin{array}{c}\text { Group I } \\
(n=43) \\
\text { Mean } \pm \text { SD }\end{array}$ & $\begin{array}{c}\text { Group II } \\
(n=22) \\
\text { Mean } \pm \text { SD }\end{array}$ & $p$ value** \\
\hline CD133 $^{+}$ & $0.0325 \pm 0.054$ & $0.0162 \pm 0.0132$ & 0.6196 \\
${\text { CD } 133^{+} / \text {VEGF-R2 }}^{+}$ & $0.0099 \pm 0.013$ & $0.0106 \pm 0.0231$ & 0.6253 \\
\hline
\end{tabular}

${ }^{* *}$ Mann-Whitney $U$ test.

between group Ia and group Ib ( $p>0.05$; Figures 1 and 2$)$. On day 7 , the numbers of stem cells $\left(\mathrm{CD} 133^{+}\right)$and early EPCs $\left(\mathrm{CD} 133^{+} / \mathrm{VEGF}-\mathrm{R} 2^{+}\right)$were significantly higher in group $\mathrm{Ib}$ than in group Ia $(p=0.0122$ and $p=0.0041$, respectively; Figures 1 and 2).

In group Ia, there was a negative correlation between $\mathrm{CD}_{133}{ }^{+}$cell number on day 7 and neurological deficit, as assessed by NIHSS, on day $1(N=25$, Rs $=-0.42, p=$ $0.0377)$, day $3(N=25, \mathrm{Rs}=-0.45, p=0.0251)$, and day $7(N=25$, Rs $=-0.58, p=0.0025)$. Additionally, in group Ia, there was a positive correlation between $\mathrm{CD}_{133^{+}}$and CD $133^{+} /$VEGF-R2 ${ }^{+}$cell numbers and concentration of hsCRP on day $1(N=32$, Rs $=0.42, p=0.0158$ and $N=32$, $\mathrm{Rs}=0.53, p=0.0018$, resp.). Moreover, the number of early EPCs $\left(\mathrm{CD} 133^{+} / \mathrm{VEGF}-\mathrm{R} 2^{+}\right.$) on day 3 was positively correlated with concentration of LDL cholesterol $(N=27$, Rs $=0.39, p=0.0452)$. 
TABLE 3: Clinical characteristics of groups Ia and Ib.

\begin{tabular}{|c|c|c|c|}
\hline Clinical feature & Group Ia $(n=33)$ & Group Ib $(n=10)$ & $p$ value \\
\hline Qualitative parameters & $n(\%)$ & $n(\%)$ & $p$ value $^{*}$ \\
\hline Male gender & $14(42.4)$ & $6(60.0)$ & 0.3289 \\
\hline \multicolumn{4}{|l|}{ Severe clinical status } \\
\hline $\mathrm{NIH} \leq 7$ & $14(42.4)$ & $3(30.0)$ & 0.4815 \\
\hline NIH 8-17 & $9(27.3)$ & $4(40.0)$ & 0.4427 \\
\hline $\mathrm{NIH}>18$ & $10(30.3)$ & $3(30.0)$ & 0.9854 \\
\hline \multicolumn{4}{|l|}{ Neurological status improvement: } \\
\hline No improvement & $11(33.3)$ & $5(50.0)$ & 0.9086 \\
\hline Improvement $<50 \%$ & $10(30.3)$ & $3(30.0)$ & 0.4665 \\
\hline Improvement $>50 \%$ or complete recovery & $12(36.4)$ & $2(20.0)$ & 0.0857 \\
\hline Death & $2(6.5)$ & $1(10.0)$ & 0.7079 \\
\hline \multicolumn{4}{|l|}{ Stroke subtypes } \\
\hline Large artery atherosclerosis & $18(54.5)$ & $6(60.0)$ & 0.5266 \\
\hline Cardioembolic & $3(9.1)$ & $1(10.0)$ & 0.6684 \\
\hline Small vessel disease & $2(6.1)$ & $1(10.0)$ & 0.5579 \\
\hline Other determined etiologies & $1(3.0)$ & $0(0)$ & 0.4963 \\
\hline Undetermined etiology & $9(27.3)$ & $2(20.0)$ & \\
\hline Hypertension & $33(100)$ & $10(100)$ & 1.0000 \\
\hline Dyslipidemia & $15(45.5)$ & $2(20.0)$ & 0.1492 \\
\hline Diabetes mellitus & $13(39.4)$ & $2(20.0)$ & 0.2596 \\
\hline Current smoker & $4(12.1)$ & $4(40.0)$ & 0.0547 \\
\hline Excessive alcohol intake & $6(18.1)$ & $2(20.0)$ & 0.8970 \\
\hline Obesity & $9(27.3)$ & $2(20.0)$ & 0.7465 \\
\hline Overweight & $15(45.5)$ & $5(50.0)$ & 0.8989 \\
\hline Coronary heart disease & $21(63.6)$ & $4(40.0)$ & 0.1844 \\
\hline Atrial fibrillation & $13(39.4)$ & $3(30.0)$ & 0.5903 \\
\hline ACE inhibitors & $33(100)$ & $0(0)$ & - \\
\hline Aspirin & $17(51.5)$ & $1(10.0)$ & 0.0197 \\
\hline Enoxaparin & $2(6.1)$ & $0(0)$ & 0.4253 \\
\hline Thrombolitic therapy & $3(9.1)$ & $3(30.0)$ & 0.1270 \\
\hline Quantitative parameters & Mean \pm SD & Mean \pm SD & $p$ value** \\
\hline Age & $76.2 \pm 9.43$ & $71.6 \pm 16.06$ & 0.4376 \\
\hline Plasma hsCRP (mg/L) & $9.6 \pm 20.63$ & $3.4 \pm 4.64$ & 0.0223 \\
\hline Plasma fibrinogen (mg/dL) & $393.8 \pm 83.98$ & $330.6 \pm 101.69$ & 0.0478 \\
\hline White blood cells (WBC) (G/L) & $9.6 \pm 9.81$ & $9.2 \pm 7.63$ & 0.8213 \\
\hline Plasma total homocysteine $(\mu \mathrm{mol} / \mathrm{L})$ & $14.8 \pm 9.77$ & $11.9 \pm 3.39$ & 0.7848 \\
\hline \multicolumn{4}{|l|}{ Lipid profile (mg/dl) } \\
\hline Total cholesterol & $178.7 \pm 45.78$ & $176.6 \pm 40.52$ & 0.8181 \\
\hline LDL cholesterol & $111.1 \pm 40.16$ & $110.9 \pm 38.65$ & 0.9313 \\
\hline HDL cholesterol & $45.5 \pm 14.26$ & $45.4 \pm 12.44$ & 0.8518 \\
\hline Triglycerides & $109.4 \pm 36.3$ & $126.2 \pm 51.05$ & 0.3652 \\
\hline
\end{tabular}

${ }^{*}$ Chi-squared test. ${ }^{* *}$ Mann-Whitney $U$ test.

Multiple linear regression analysis showed that ASA dose and the levels of hsCRP and fibrinogen, which were significantly higher in group Ia, were not independent factors significantly influencing the numbers of circulating stem cells $\left(\mathrm{CD} 133^{+}\right)$and early EPCs (CD133+/VEGF-R2 ${ }^{+}$), and the only independent factor significantly associated with the lower number of these cells on day 7 after AIS was ACEI treatment $\left(p=0.0290\right.$ for $\mathrm{CD}_{133^{+}}$and $p=0.0019$ for CD133+/VEGF-R2 ${ }^{+}$).

\section{Discussion}

This study comprised four major findings. First, in AIS patients, the numbers of circulating stem cells $\left(\mathrm{CD} 133^{+}\right)$ 
TABLE 4: Circulating stem cells $\left(\mathrm{CD} 133^{+}\right)$on subsequent days $(1,3$, and 7) of AIS in groups Ia and Ib.

\begin{tabular}{lcc}
\hline $\begin{array}{l}\text { Study population } \\
\text { (Number of cells } / \mu \mathrm{L})\end{array}$ & $\begin{array}{c}\text { Group Ia } \\
(n=33) \\
\text { Mean } \pm \text { SD }\end{array}$ & $\begin{array}{c}\text { Group Ib } \\
(n=10) \\
\text { Mean } \pm \text { SD }\end{array}$ \\
\hline${\mathrm{CD} 133^{+}{ }_{-} 1}_{\mathrm{CD} 133^{+}{ }_{-}}$ & $0.0331 \pm 0.07$ & $0.0194 \pm 0.02$ \\
$\mathrm{CD} 133^{+}{ }^{7}$ & $0.0171 \pm 0.01$ & $0.0195 \pm 0.01$ \\
\hline
\end{tabular}

TABle 5: Circulating early EPCs $\left(\mathrm{CD} 133^{+} / \mathrm{VEGFR}^{+}\right)$on subsequent days $(1,3$, and 7$)$ of AIS in group Ia.

\begin{tabular}{|c|c|c|}
\hline $\begin{array}{l}\text { Study population } \\
\text { (Number of cells/ } \mu \mathrm{L} \text { ) }\end{array}$ & $\begin{array}{c}\text { Group Ia } \\
(n=33) \\
\text { Mean } \pm \text { SD }\end{array}$ & $\begin{array}{c}\text { Group Ib } \\
(n=10) \\
\text { Mean } \pm \text { SD }\end{array}$ \\
\hline${\mathrm{CD} 133^{+} / \text {VEGF-R2 }{ }^{+} \_1}$ & $0.0103 \pm 0.02$ & $0.0062 \pm 0.007$ \\
\hline $\mathrm{CD} 133^{+} /$VEGF-R2 ${ }^{+}{ }^{3}$ & $0.0044 \pm 0.03$ & $0.0064 \pm 0.005$ \\
\hline $\mathrm{CD}_{133^{+}} / \mathrm{VEGF}-\mathrm{R} 2^{+}{ }^{+} 7$ & $0.0033 \pm 0.001$ & $0.0102 \pm 0.006$ \\
\hline
\end{tabular}

and early EPCs $\left(\mathrm{CD} 133^{+} / \mathrm{VEGFR} 2^{+}\right)$upon admission were similar to those in control individuals without AIS; however, the risk factors were similar. Second, there were no significant changes in the numbers of stem cells $\left(\mathrm{CD}_{133^{+}}\right)$and early EPCs $\left(\mathrm{CD} 133^{+} / \mathrm{VEGF}-\mathrm{R}^{+}\right)$at subsequent days after AIS. Third, chronic treatment with ACEIs does not increase the number of circulating stem cells $\left(\mathrm{CD}_{133^{+}}\right)$and early EPCs $\left(\mathrm{CD}_{133^{+}}{ }^{\mathrm{VEEGFR}}{ }^{+}\right)$in AIS, and in fact, it is an independent factor associated with lower numbers of these cells on day 7 after AIS. Lastly, in AIS patients chronically treated with an ACEI, the number of $\mathrm{CD}_{13}{ }^{+}$cells was negatively correlated with neurological deficit.

Ghani et al., Chu et al., and Zhou et al. reported a reduction in EPCs among patients with cerebrovascular diseases, compared to that in healthy controls [14-16]. However, these data are inconsistent as other authors found higher EPC counts in stroke patients than in controls [17, 21]. Yip et al. [18] showed that the levels of circulating EPCs $\left(\mathrm{CD} 31^{+} / \mathrm{CD} 34^{+}, \mathrm{CD}_{2} \mathrm{E}^{+} / \mathrm{CD} 34^{+}\right)$and $\left(\mathrm{KDR}^{+} / \mathrm{CD} 34^{+}\right)$were significantly higher among patients with AIS than in the at-risk control subjects. Paczkowska et al. [19] reported a significantly higher percentage of early EPCs only in hemorrhagic stroke patients as opposed to those with AIS. Our study shows that the number of circulating EPCs is similar between acute stroke patients and risk factor control cases. A number of variables such as age or distribution of risk factors, time from stroke onset to blood collection, EPC definition, EPC measurements, and statistical methods performed in different papers might account for these discrepancies.

After ischemic injury, the release of cytokines and trophic factors might induce an increase in the production and mobilization of EPCs [37]. This occurs in patients with acute coronary syndrome and acute ischemic stroke, with a peak in EPC counts and vascular endothelial growth factor (VEGF) levels occurring on the seventh day after the ischemic event $[16,38-40]$. However, one study reported stable
EPC counts, whereas another reported the intermittent release of EPCs after ischemic stroke $[15,17]$. In our study, we confirmed stable levels of $\mathrm{CD}_{133^{+}}$and $\mathrm{CD}_{133^{+}}$/ VEGFR2 $^{+}$cells in AIS.

In previous studies involving patients with myocardial infarction, a higher number of EPCs were associated with better prognosis, increased myocardial salvage, and more collateral in the ischemic zone $[41,42]$. However, the impact of the number of circulating EPCs on clinical outcomes after stroke in men remains uncertain. Previous studies have shown that low circulating EPC levels are independently predictive of severe neurologic impairment and major adverse clinical outcomes in patients with AIS [18]. According to another study regarding patients after AIS, good neurological and functional outcome, reduced infarct growth, and neurological improvement have been associated with the increase of EPCs [43]. Probably, in addition to the severity of the stroke, the number of circulating EPCs is influenced by other factors such as age, comorbidities, and drugs used [44, 45]. However, the increased number of circulating EPCs is thought to play an important role in endogenous vascular repair and in the maintenance of endothelial integrity in the adult brain after ischemic stress [46, 47].

EPCs activated by perindopril could contribute to ongoing endothelial repair by providing a circulating pool of cells that can be home to injured parts of the artery or replace dysfunctional endothelial cells [8]. Additionally, EPCs, once mobilized into the peripheral circulation, penetrate the infarct and are involved in the formation of new vessels [48], which then improves blood supply in the ischemic penumbra, finally leading to a decreased infarction area after AIS [49]. The significant activation of EPCs might be associated with the different effects of ACEIs themselves, including inhibiting bradykinin degradation, increasing cGMP in vascular endothelial cells, restraining renin-angiotensin system activity, and decreasing the production of oxygen free radicals, which leads to sensitized NO synthase and increased NO release. All of these effects can, in turn, induce EPC mobilization from the bone marrow [50].

We observed that chronic treatment with ACEIs does not additionally increase the number of circulating stem cells $\left(\mathrm{CD} 133^{+}\right)$and early EPCs $\left(\mathrm{CD} 133^{+} / \mathrm{VEGFR} 2^{+}\right)$in AIS. In contrast, our results demonstrate the existence of a statistically significant relationship between the number of $\mathrm{CD}_{133^{+}}$cells and neurological deficit, as assessed by NIHSS. On the seventh day after ASI, a negative correlation between $\mathrm{CD}_{133^{+}}$and NIHSS score was found, which could be the result of improved circulation in the ischemic penumbra mediated by a positive influence of $\mathrm{CD}_{133^{+}}$ cells on the endothelial regeneration of damaged vessels or even on the formation of new vessels. Consequently, this mechanism could promote a reduction in the neurological deficit. The interpretation of the results from the first and third days is difficult. We can assume that the severity of the neurological deficit is first correlated with neural tissue necrosis and compensative mechanisms are not sufficient.

In terms of prognosis after AIS, ACEIs seem to be a promising option for the treatment of AIS and for the 


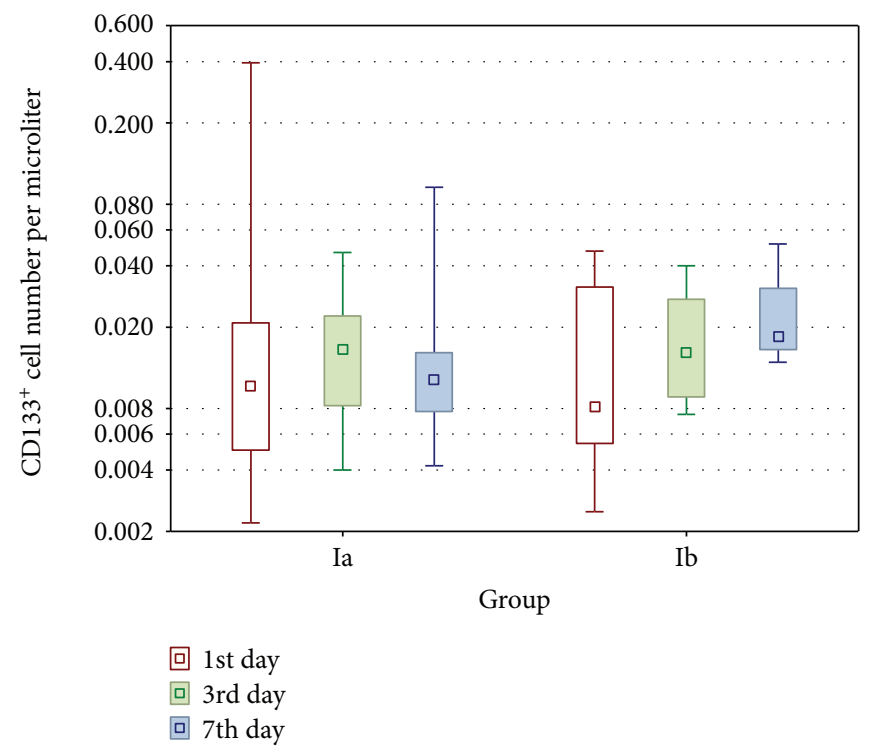

Figure 1: The populations of circulating stem cells $\left(\mathrm{CD}_{13} 3^{+}\right)$in groups Ia and $\mathrm{Ib}$ on the $1 \mathrm{st}$, 3rd, and 7th days. On the 7th day, the number of cells was significantly higher in group $\mathrm{Ib}(p<0.05$, Mann-Whitney $U$ test).

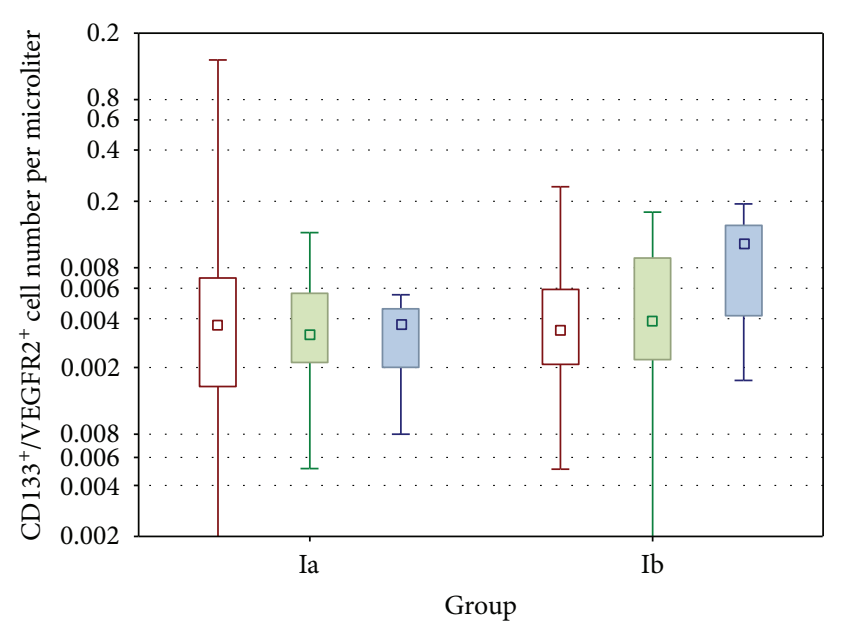

回 1st day

(1) 2nd day

口 3rd day

Figure 2: The populations of early EPCs $\left(\mathrm{CD} 133^{+} / \mathrm{VEGFR} 2^{+}\right)$in groups Ia and Ib on the 1st, 3rd, and 7th days. On the 7th day, the number of cells was significantly higher in group $\mathrm{Ib}(p<0.05$, Mann-Whitney $U$ test).

primary prevention of cerebrovascular events. Many factors, including growth factors, chemokines, proinflammatory cytokines, chemokines, hormones, and lipid-lowering and antidiabetic drugs, have been regarded as important factors involved in EPC mobilization [51].

Circulating hsCRP represents a potential independent predictor of vascular damage [52]. Initially proposed as a biomarker, hsCRP was subsequently suggested as a player in atherogenesis [53], although its role has not been definitely defined [54]. Verma et al. demonstrated that EPCs incubated with human recombinant CRP, at concentrations known to predict adverse vascular outcomes, exhibited decreased survival and increased apoptosis. Moreover, the reduction of EPCs appears to be hsCRP dose-dependent $[55,56]$.

Fibrinogen is an inflammatory marker and is closely related to atherosclerosis [57-59].

Indeed, Mandraffino et al. [60] showed a strong correlation between inflammatory markers (including CRP and fibrinogen) and EPC levels in several different clinical settings (smokers, arthritis patients, and hypertensive patients with and without left ventricular hypertrophy); here, it was stated that "CD34+ cell count change at T1 appeared to be mainly correlated with fibrinogen reduction $(\mathrm{Rs}=-0.625$, $p<0.001)$." This group also proposed different mechanisms through which inflammation (including mediators, cytokines, receptors, and microRNAs), and also RAAS modulation (including drug intervention) might affect the EPC number [53-58]. Moreover, the relationships between fibrinogen and EPCs have also been evaluated in elderly individuals, where inflammatory markers appear to lose their predictive ability [59]. Our study showed that serum fibrinogen and hsCRP levels were significantly higher in group Ia, although multiple linear regression did not reveal them to be independent factors affecting EPC mobilization.

Our study has several limitations. First, it lacks the detection of appropriate cell surface markers specific for the identification of EPCs in the field of EPC research. The conflicting results might be due to different methodologies used to identify circulating EPCs. Second, the study was performed using a small sample size of 43 subjects, and the results require further confirmation in larger cohorts. Third, the number of circulating EPCs is influenced by many factors and the basal levels of EPCs from each patient are not known, specifically, steady-state levels and levels immediately before the acute vascular event; thus, it is difficult to assess whether levels were changed on an individual basis. Fourth, the duration of hypertension 
and antihypertensive treatment could have a role in influencing the association between the use of ACEI and EPC mobilization. However, the actual duration of hypertension in our patients was impossible to determine. Similarly, data regarding the length of ACEI therapy could not be reliably determined. Furthermore, we measured the number of EPCs, but not their function; however, numbers and functional integrity are coregulated by the same molecular pathways, and therefore, a decrease in EPC numbers is usually associated with a corresponding decrease in function and vice versa.

\section{Conflicts of Interest}

No potential conflicts of interest are reported.

\section{References}

[1] O. Hurtado, J. M. Pradillo, D. Alonso-Escolano et al., "Neurorepair versus neuroprotection in stroke," Cerebrovascular Diseases, vol. 21, no. 2, pp. 54-63, 2006.

[2] S. H. Graham and J. Chen, "Programmed cell death in cerebral ischemia," Journal of Cerebral Blood Flow \& Metabolism, vol. 21, no. 2, pp. 99-109, 2001.

[3] T. Sairanen, O. Carpen, M.-L. Karjalainen-Lindsberg et al., "Evolution of cerebral tumor necrosis factor- $\alpha$ production during human ischemic stroke," Stroke, vol. 32, no. 8, pp. 1750-1758, 2001.

[4] E. Mannarino and M. Pirro, "Endothelial injury and repair: a novel theory for atherosclerosis," Angiology, vol. 59, Supplement 2, pp. 69S-72S, 2008.

[5] T. Asahara, H. Masuda, T. Takahashi et al., "Bone marrow origin of endothelial progenitor cells responsible for postnatal vasculogenesis in physiological and pathological neovascularization," Circulation Research, vol. 85, no. 3, pp. 221-228, 1999.

[6] C. Urbich and S. Dimmeler, "Endothelial progenitor cells: characterization and role in vascular biology," Circulation Research, vol. 95, no. 4, pp. 343-353, 2004.

[7] J. M. Hill, G. Zalos, J. P. J. Halcox et al., "Circulating endothelial progenitor cells, vascular function, and cardiovascular risk," New England Journal of Medicine, vol. 348, no. 7, pp. 593-600, 2003.

[8] E. Shantsila, T. Watson, and G. Y. H. Lip, "Endothelial progenitor cells in cardiovascular disorders," Journal of the American College of Cardiology, vol. 49, no. 7, pp. 741-752, 2007.

[9] M. Vasa, S. Fichtlscherer, A. Aicher et al., "Number and migratory activity of circulating endothelial progenitor cells inversely correlate with risk factors for coronary artery disease," Circulation Research, vol. 89, no. 1, pp. E1-E7, 2001.

[10] C. Schmidt-Lucke, L. Rössig, S. Fichtlscherer et al., "Reduced number of circulating endothelial progenitor cells predicts future cardiovascular events: proof of concept for the clinical importance of endogenous vascular repair," Circulation, vol. 111, no. 22, pp. 2981-2987, 2005.

[11] C. Bakogiannis, D. Tousoulis, E. Androulakis et al., "Circulating endothelial progenitor cells as biomarkers for prediction of cardiovascular outcomes," Current Medicinal Chemistry, vol. 19, no. 16, pp. 2597-2604, 2012.

[12] N. Werner, S. Kosiol, T. Schiegl et al., "Circulating endothelial progenitor cells and cardiovascular outcomes," New England Journal of Medicine, vol. 353, no. 10, pp. 999-1007, 2005.
[13] K. Chu, K. H. Jung, S. T. Lee et al., "Circulating endothelial progenitor cells as a new marker of endothelial dysfunction or repair in acute stroke," Stroke, vol. 39, no. 5, pp. 1441$1447,2008$.

[14] U. Ghani, A. Shuaib, A. Salam et al., "Endothelial progenitor cells during cerebrovascular disease," Stroke, vol. 36, no. 1, pp. 151-153, 2005.

[15] W. J. Zhou, D. L. Zhu, G. Y. Yang et al., "Circulating endothelial progenitor cells in Chinese patients with acute stroke," Hypertension Research, vol. 32, no. 4, pp. 306-310, 2009.

[16] A. Dunac, C. Frelin, M. Popolo-Blondeau, M. Chatel, M. H. Mahagne, and P. J.-M. Philip, "Neurological and functional recovery in human stroke are associated with peripheral blood CD34+ cell mobilization," Journal of Neurology, vol. 254, no. 3, pp. 327-332, 2007.

[17] H.-K. Yip, L.-T. Chang, W.-N. Chang et al., "Level and value of circulating endothelial progenitor cells in patients after acute ischemic stroke," Stroke, vol. 39, no. 1, pp. 69-74, 2008.

[18] H. K. Yip, T. H. Tsai, H. S. Lin et al., "Effect of erythropoietin on level of circulating endothelial progenitor cells and outcome in patients after acute ischemic stroke," Critical Care, vol. 15, no. 1, p. R40, 2011.

[19] E. Paczkowska, M. Gołąb-Janowska, A. Bajer-Czajkowska et al., "Increased circulating endothelial progenitor cells in patients with haemorrhagic and ischaemic stroke: the role of Endothelin-1," Journal of the Neurological Sciences, vol. 325, no. 1-2, pp. 90-99, 2013.

[20] M. Navarro-Sobrino, A. Rosell, M. Hernandez-Guillamon et al., "Mobilization, endothelial differentiation and functional capacity of endothelial progenitor cells after ischemic stroke," Microvascular Research, vol. 80, no. 3, pp. 317-323, 2010.

[21] D. You, C. Cochain, C. Loinard et al., "Combination of the angiotensin-converting enzyme inhibitor perindopril and the diuretic indapamide activate postnatal vasculogenesis in spontaneously hypertensive rats," Journal of Pharmacology and Experimental Therapeutics, vol. 325, no. 3, pp. 766-773, 2008.

[22] P. Muller, A. Kazakov, P. Jagoda, A. Semenov, M. Bohm, and U. Laufs, "ACE inhibition promotes upregulation of endothelial progenitor cells and neoangiogenesis in cardiac pressure overload," Cardiovascular Research, vol. 83, no. 1, pp. 106114, 2009.

[23] C. H. Wang, S. Verma, I. C. Hsieh et al., "Enalapril increases ischemia-induced endothelial progenitor cell mobilization through manipulation of the CD26 system," Journal of Molecular and Cellular Cardiology, vol. 41, no. 1, pp. 34-43, 2006.

[24] K. J. McConnell, T. L. Humphries, M. A. Raebel, J. A. Merenich, and Clinical Pharmacy Cardiac Risk Service Study Group, "Clinical pharmacy specialist implementation of lisinopril therapy in patients with coronary artery disease and diabetes mellitus," Pharmacotherapy, vol. 23, no. 12, pp. 1564-1572, 2003.

[25] J. E. Toblli, G. Cao, G. DeRosa, F. Di Gennaro, and P. Forcada, "Angiotensin-converting enzyme inhibition and angiogenesis in myocardium of obese Zucker rats," American Journal of Hypertension, vol. 17, no. 2, pp. 172-180, 2004.

[26] T. Asahara, T. Takahashi, H. Masuda et al., "VEGF contributes to postnatal neovascularization by mobilizing bone marrowderived endothelial progenitor cells," The EMBO Journal, vol. 18, no. 14, pp. 3964-3972, 1999. 
[27] Y.-F. Li, L.-N. Ren, G. Guo et al., "Endothelial progenitor cells in ischemic stroke: an exploration from hypothesis to therapy," Journal of Hematology \& Oncology, vol. 8, no. 1, p. 33, 2015.

[28] J. T. L. Wilson, A. Hareendran, A. Hendry, J. Potter, I. Bone, and K. W. Muir, "Reliability of the modified rankin scale across multiple raters: benefits of a structured interview," Stroke, vol. 36, no. 4, pp. 777-781, 2005.

[29] L. K. Kwah and J. Diong, "National Institutes of Health Stroke Scale (NIHSS)," Journal of Physiotherapy, vol. 60, no. 1, p. 61, 2014.

[30] A. J. Camm, P. Kirchhof, G. Y. H. Lip et al., "Wytyczne dotyczące postępowania $\mathrm{u}$ chorych $\mathrm{z}$ migotaniem przedsionków Grupa Robocza Europejskiego Towarzystwa Kardiologicznego (ESC) do spraw postępowania $\mathrm{u}$ chorych $\mathrm{z}$ migotaniem przedsionków Opracowane przy szczególnym udziale EHRA (European Heart Rhythm Association) ${ }^{+}$ Zaakceptowane przez EACTS (European Association for Cardio-Thoracic Surgery)," Kardiologia Polska, vol. 68, Supplement VII, pp. 487-566, 2010.

[31] M. R. Ortiz, E. Romo, D. Mesa et al., "Predicting embolic events in patients with nonvalvular atrial fibrillation: evaluation of the $\mathrm{CHADS}_{2}$ score in a mediterranean population," Revista Española de Cardiología, vol. 61, no. 1, pp. 29-35, 2008.

[32] J. B. Olesen, G. Y. H. Lip, M. L. Hansen et al., "Validation of risk stratification schemes for predicting stroke and thromboembolism in patients with atrial fibrillation: nationwide cohort study," BMJ, vol. 342, p. d124, 2011.

[33] J. Rehm, R. Room, M. Monteiro et al., "Alcohol use," in Comparative Quantification of Health Risks: Global and Regional Burden of Disease Attributable to Selected Major Risk Factors, M. Ezzati, A. D. Lopez, A. Rodgers, and M. ChJL, Eds., pp. 959-1108, World Health Organization, Geneva, 2004.

[34] K. Umetani, Y. Kodama, T. Nakamura et al., "High prevalence of paroxysmal atrial fibrillation and/or atrial flutter in metabolic syndrome," Circulation Journal, vol. 71, no. 2, pp. 252255, 2007.

[35] H. Ay, K. L. Furie, A. Singhal, W. S. Smith, A. G. Sorensen, and W. J. Koroshetz, "An evidence-based causative classification system for acute ischemic stroke," Annals of Neurology, vol. 58, no. 5, pp. 688-697, 2005.

[36] K. H. Jung and J. K. Roh, "Circulating endothelial progenitor cells in cerebrovascular disease," Journal of Clinical Neurology, vol. 4, no. 4, pp. 139-147, 2008.

[37] S. Shintani, T. Murohara, H. Ikeda et al., "Mobilization of endothelial progenitor cells in patients with acute myocardial infarction," Circulation, vol. 103, no. 23, pp. 2776-2779, 2001.

[38] J. Martí-Fàbregas, J. Crespo, R. Delgado-Mederos et al., "Endothelial progenitor cells in acute ischemic stroke," Brain and Behavior, vol. 3, no. 6, pp. 649-655, 2013.

[39] T. Sobrino, M. Pérez-Mato, D. Brea, M. Rodríguez-Yáñez, M. Blanco, and J. Castillo, "Temporal profile of molecular signatures associated with circulating endothelial progenitor cells in human ischemic stroke," Journal of Neuroscience Research, vol. 90, no. 9, pp. 1788-1793, 2012.

[40] E. I. Lev, N. S. Kleiman, Y. Birnbaum, D. Harris, M. Korbling, and Z. Estrov, "Circulating endothelial progenitor cells and coronary collaterals in patients with non-ST segment elevation myocardial infarction," Journal of Vascular Research, vol. 42, no. 5, pp. 408-414, 2005.
[41] T. Sobrino, O. Hurtado, M. A. Moro et al., "The increase of circulating endothelial progenitor cells after acute ischemic stroke is associated with good outcome," Stroke, vol. 38, no. 10, pp. 2759-2764, 2007.

[42] G. P. Fadini, M. Miorin, M. Facco et al., "Circulating endothelial progenitor cells are reduced in peripheral vascular complications of type 2 diabetes mellitus," Journal of the American College of Cardiology, vol. 45, no. 9, pp. 1449-1457, 2005.

[43] C. Heiss, S. Keymel, U. Niesler, J. Ziemann, M. Kelm, and C. Kalka, "Impaired progenitor cell activity in age-related endothelial dysfunction," Journal of the American College of Cardiology, vol. 45, no. 9, pp. 1441-1448, 2005.

[44] A. Taguchi, T. Soma, H. Tanaka et al., "Administration of $\mathrm{CD} 34^{+}$cells after stroke enhances neurogenesis via angiogenesis in a mouse model," Journal of Clinical Investigation, vol. 114, no. 3, pp. 330-338, 2004.

[45] Z. G. Zhang, L. Zhang, Q. Jiang, and M. Chopp, "Bone marrow-derived endothelial progenitor cells participate in cerebral neovascularization after focal cerebral ischemia in the adult mouse," Circulation Research, vol. 90, no. 3, pp. 284-288, 2002.

[46] B. D. Westenbrink, H. Oeseburg, L. Kleijn et al., "Erythropoietin stimulates normal endothelial progenitor cell-mediated endothelial turnover, but attributes to neovascularization only in the presence of local ischemia," Cardiovascular Drugs and Therapy, vol. 22, no. 4, pp. 265-274, 2008.

[47] E. P. Davidson, L. J. Coppey, A. Holmes, and M. A. Yorek, "Effect of inhibition of angiotensin converting enzyme and/ or neutral endopeptidase on vascular and neural complications in high fat fed/low dose streptozotocin-diabetic rats," European Journal of Pharmacology, vol. 677, no. 1-3, pp. $180-187,2012$.

[48] A. Aicher, C. Heeschen, C. Mildner-Rihm et al., "Essential role of endothelial nitric oxide synthase for mobilization of stem and progenitor cells," Nature Medicine, vol. 9, no. 11, pp. 1370-1376, 2003.

[49] C. Urbich, A. Aicher, C. Heeschen et al., "Soluble factors released by endothelial progenitor cells promote migration of endothelial cells and cardiac resident progenitor cells," Journal of Molecular and Cellular Cardiology, vol. 39, no. 5, pp. 733742, 2005.

[50] P. M. Ridker, M. J. Stampfer, and N. Rifai, "Novel risk factors for systemic atherosclerosis: a comparison of C-reactive protein, fibrinogen, homocysteine, lipoprotein(a), and standard cholesterol screening as predictors of peripheral arterial disease," JAMA, vol. 285, no. 19, pp. 2481-2485, 2001.

[51] P. E. Szmitko, C. H. Wang, R. D. Weisel, J. R. de Almeida, T. J. Anderson, and S. Verma, "New markers of inflammation and endothelial cell activation. Part I," Circulation, vol. 108, no. 16, pp. 1917-1923, 2003.

[52] R. Ruckerl, A. Peters, N. Khuseyinova et al., "Determinants of the acute-phase protein C-reactive protein in myocardial infarction survivors: the role of comorbidities and environmental factors," Clinical Chemistry, vol. 55, no. 2, pp. 322335, 2009.

[53] S. Verma, M. A. Kuliszewski, S. H. Li et al., "C-reactive protein attenuates endothelial progenitor cell survival, differentiation, and function: further evidence of a mechanistic link between C-reactive protein and cardiovascular disease," Circulation, vol. 109, no. 17, pp. 2058-2067, 2004.

[54] R. G. Turan, M. Brehm, M. Koestering et al., "Factors influencing spontaneous mobilization of CD34+ and CD133+ 
progenitor cells after myocardial infarction," European Journal of Clinical Investigation, vol. 37, no. 11, pp. 842-851, 2007.

[55] M. Guo, S. K. Sahni, A. Sahni, and C. W. Francis, "Fibrinogen regulates the expression of inflammatory chemokines through NF- $\kappa \mathrm{B}$ activation of endothelial cells," Thrombosis and Haemostasis, vol. 92, no. 4, pp. 858-866, 2004.

[56] R. I. Thacker and G. S. Retzinger, "Adsorbed fibrinogen regulates the behavior of human dendritic cells in a CD18dependent manner," Experimental and Molecular Pathology, vol. 84, no. 2, pp. 122-130, 2008.

[57] R. S. Eidelman and C. H. Hennekens, "Fibrinogen: a predictor of stroke and marker of atherosclerosis," European Heart Journal, vol. 24, no. 6, pp. 499-500, 2003.

[58] G. Mandraffino, M. A. Sardo, S. Riggio et al., "Smoke exposure and circulating progenitor cells: evidence for modulation of antioxidant enzymes and cell count," Clinical Biochemistry, vol. 43, no. 18, pp. 1436-1442, 2010.

[59] G. Mandraffino, C. O. Aragona, V. Cairo et al., "Circulating progenitor cells in hypertensive subjects: effectiveness of a treatment with olmesartan in improving cell number and miR profile in addition to expected pharmacological effects," PLoS One, vol. 12, no. 3, article e0173030, 2017.

[60] G. Mandraffino, E. Imbalzano, M. A. Sardo et al., "Circulating progenitor cells in hypertensive patients with different degrees of cardiovascular involvement," Journal of Human Hypertension, vol. 28, no. 9, pp. 543-550, 2014. 


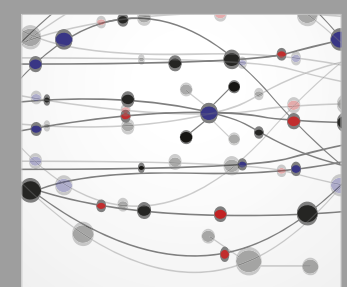

The Scientific World Journal
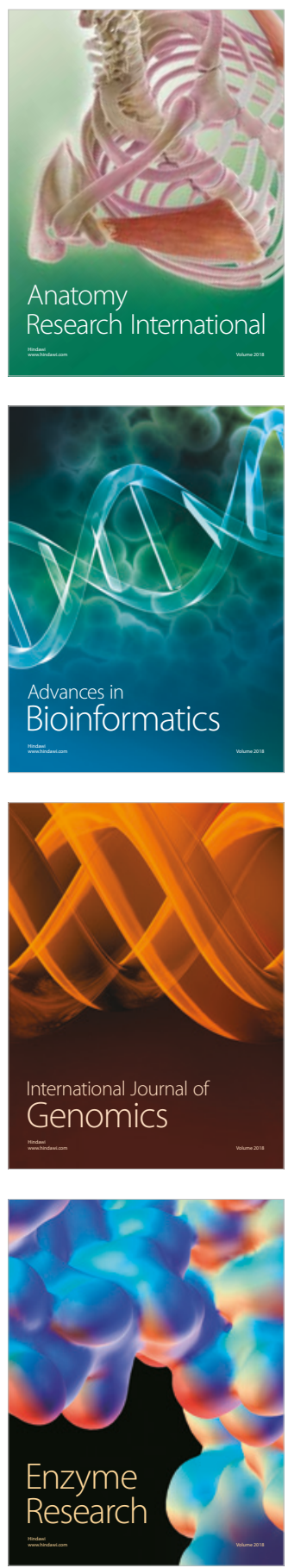
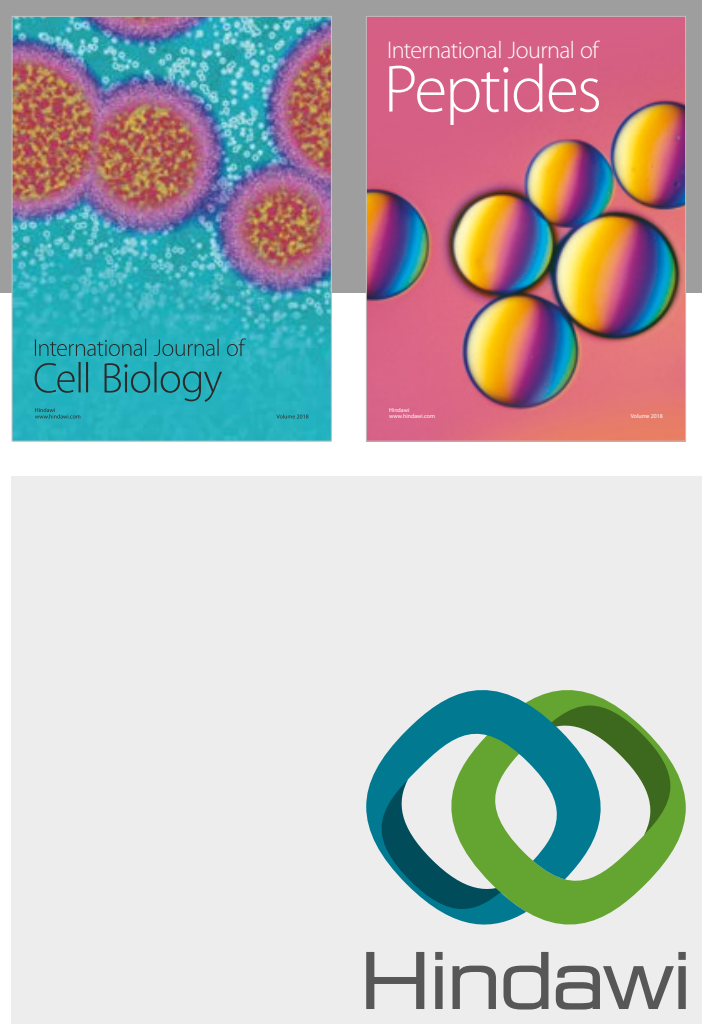

Submit your manuscripts at

www.hindawi.com
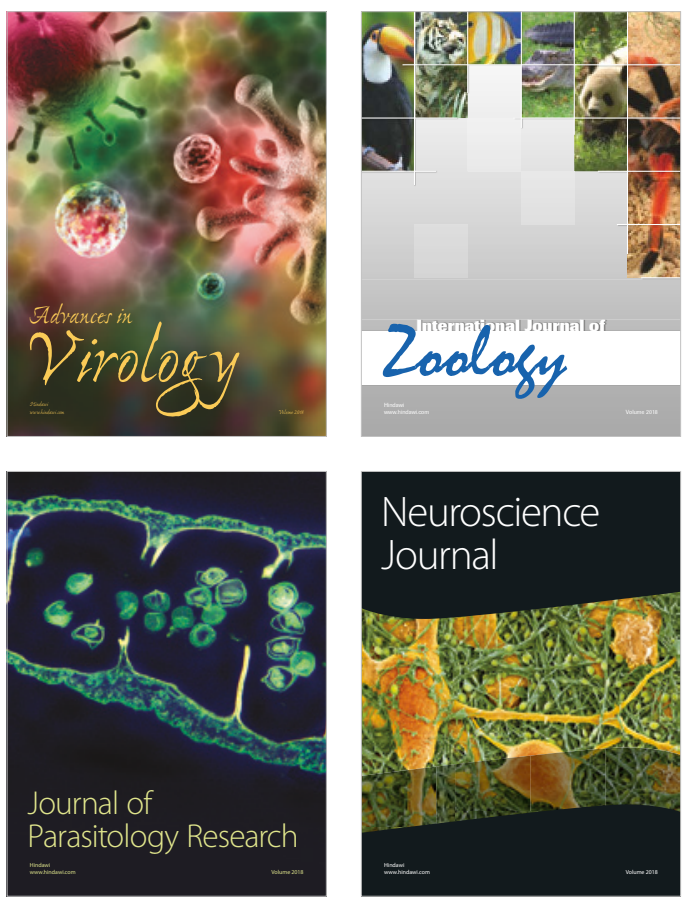
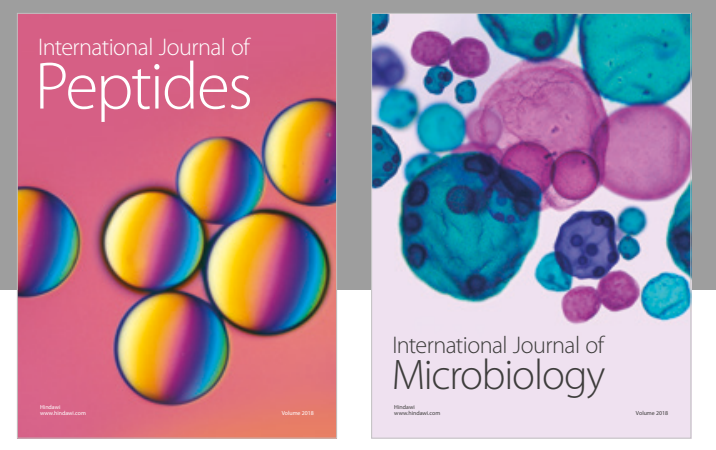

nternational Journal of Microbiology
Journal of
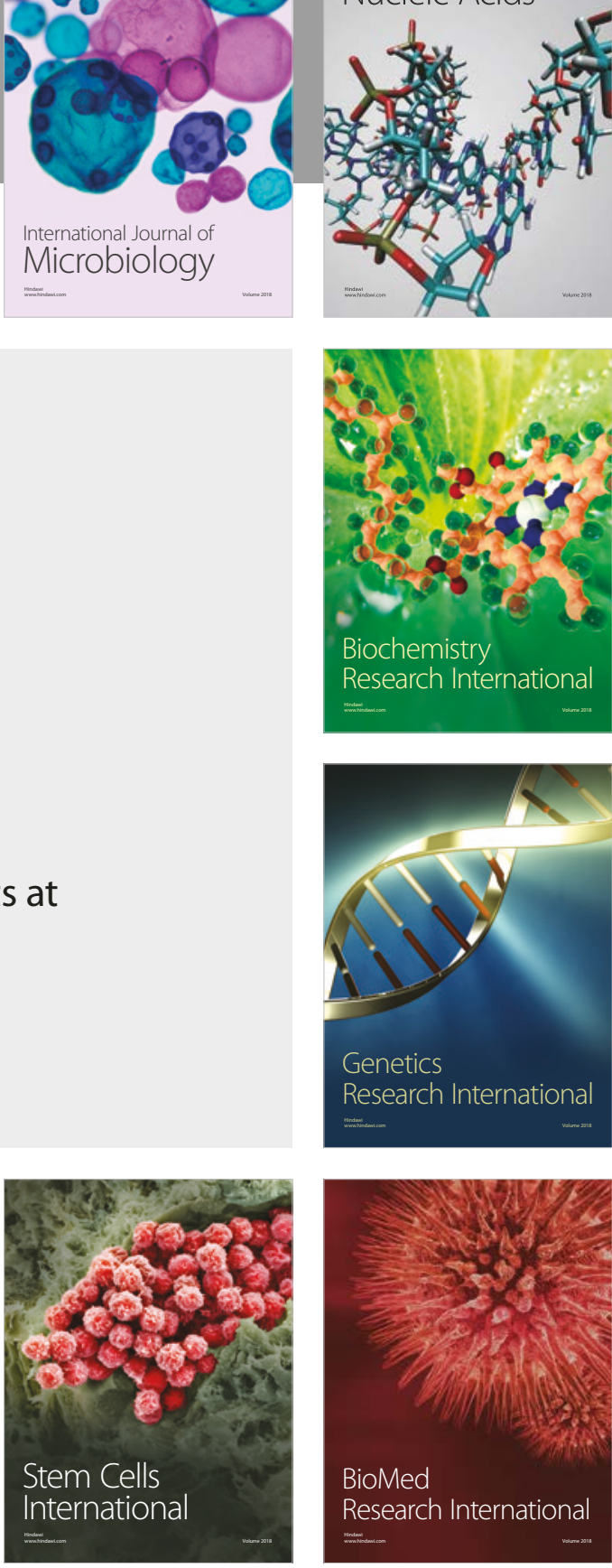
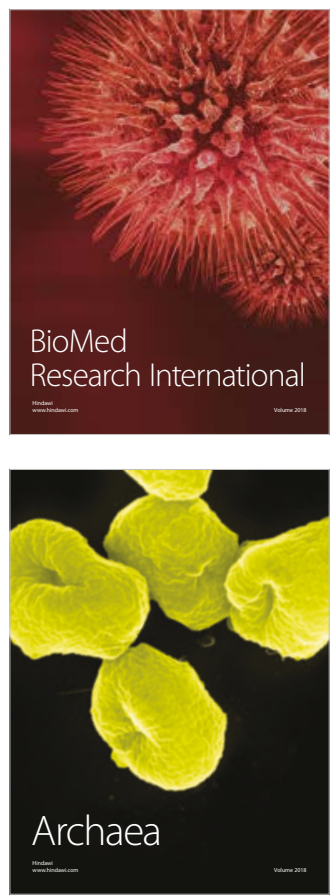